\title{
To institute conflictive cooperation on the quality of work
}

\author{
Instituir a cooperação conflitante sobre a qualidade do trabalho
}

Instituir la cooperación conflictiva sobre la calidad del trabajo

Instituer la coopération conflictuelle sur la qualité du travail

\author{
JEAN-YVES BONNEFOND* \\ ANTOINE BONNEMAIN** \\ FLÁVIO FERNANDES FONTES*** \\ YVES CLOT****
}

\begin{abstract}
Activity Clinic is an active methodology to change work. We show how an experimental device on the quality of work is established at the Flins factory, after a request from Renault corporation. The method of crossed self-confrontation is used with operators of an assembly unit of doors. The results produced are discussed with management, direction and unions. The quality of the analysis and of the dialogue practiced in the device has helped solve performance and health problems that were initially ignored or repressed, as in the example of assembling a given part (coulisse). The recognition of the value of the experience made "at the doors" leads to the design and generalization of an organizational device throughout the assembly department. By the end of 2015, it was deployed in five departments of the factory, where a different "social dialogue" is being developed in the service of sustainable performance, conceived also as a source of health.
\end{abstract}

Keywords: occupational health; job performance; quality of work.

\begin{abstract}
RESUMO
A Clínica da Atividade é uma metodologia de ação para mudar o trabalho. Nós mostramos como um dispositivo experimental sobre a qualidade do trabalho é instituído na usina de Flins, a partir de uma demanda da empresa Renault. O método da autoconfrontação cruzada é utilizado com operadores de uma unidade de montagem de portas. Os resultados produzidos são objeto de um diálogo com a equipe no atelier e nos comitês de acompanhamento com a direção e sindicatos. A qualidade das análises e dos diálogos instituídos assim em diferentes níveis permitiu responder a problemas de desempenho e saúde ignorados ou reprimidos, como no exemplo da montagem de uma peça (coulisse). O reconhecimento do valor da experiência feita "com as portas" leva à concepção e generalização de um dispositivo organizacional em todo o departamento de montagem. No fim de 2015 o dispositivo é desenvolvido nos cinco departamentos de fabricação da usina, onde se desenvolve outro "diálogo social" a serviço de um desempenho durável, fonte de saúde.
\end{abstract}

Palavras-chave: Saúde ocupacional. Desempenho no trabalho. Qualidade do trabalho.

\section{RESUMEN}

La Clínica de la Actividad es una metodología de acción para cambiar el trabajo. Mostramos cómo un dispositivo experimental sobre la calidad del trabajo es instituido en la fábrica de Flins, a partir de una demanda de la empresa Renault. El método de la auto-confrontación cruzada es utilizado con los operadores de una unidad de montaje de puertas. Los resultados obtenidos son objeto de un diálogo con el personal del taller y en los comités de acompañamiento con la dirección y los sindicatos. La calidad del análisis y diálogos instituidos en diferentes niveles ha permitido responder a problemas de desempeño y salud ignorados o reprimidos, como en el ejemplo de montaje de una parte (coulisse). El reconocimiento del valor de la experiencia hecha "con las puertas" conduce al diseño y la

\footnotetext{
* Conservatoire National des Arts et Métiers (CNAM), Centre de Recherche sur le Travail et le Développement (CRTD), équipe de Psychologie du Travail et Clinique de l'Activité. E-mail: <jeanyves.bonnefond@cnam.fr>.

** Conservatoire National des Arts et Métiers (CNAM), Centre de Recherche sur le Travail et le Développement (CRTD), équipe de Psychologie du Travail et Clinique de l'Activité. E-mail: <antoinebonnemain@yahoo.fr>.

*** Universidade Federal do Rio Grande do Norte (UFRN), Grupo de Estudos e Pesquisas sobre o Trabalho (GEPET). E-mail: <flaviofontes@outlook.com>.

**** Conservatoire National des Arts et Métiers (CNAM), Centre de Recherche sur le Travail et le Développement (CRTD), équipe de Psychologie du Travail et Clinique de l'Activité. E-mail: <yves.clot@cnam.fr>.
} 
generalización de un dispositivo de organización en todo el departamento de montaje. En el fin de 2015 él es utilizado en los cinco departamentos de fabricación de la fábrica, donde se desarrolla otro "diálogo social" que trabaja para un rendimiento duradero, fuente de salud.

Palabras clave: Salud ocupacional. Rendimiento laboral. Calidad del trabajo.

\section{RÉSUMÉ}

La Clinique de l'Activité est une méthodologie d'action pour changer le travail. Nous montrons comment un dispositif expérimental sur la qualité du travail est institué à l'usine de Flins, d'après une demande de l'entreprise Renault. La méthode des autoconfrontations croisées est utilisée avec des opérateurs d'une unité de montage des portes. Les résultats produits font l'objet d'un dialogue avec l'encadrement dans l'atelier et au sein des comités de suivi avec direction et syndicats. La qualité des analyses et des dialogues instituées ainsi à plusieurs niveaux ont permis de répondre à des problèmes de performance et santé ignorés ou refoulés, comme dans l'exemple du montage d'une pièce (coulisse). La reconnaissance de la valeur de l'expérience faite "aux portes" amène à la conception et la généralisation d'un dispositif organisationnel dans tout le département montage. Fin 2015, il est déployé dans les cinq départements de fabrication de l'usine, où se développe un autre « dialogue social » au service d'une performance durable, source de santé.

Mots-clés: Santé au travail. Performance. Qualité du travail.

\section{INTRODUCTION $^{1}$}

When it comes to mental health at work, there are two main approaches: the first one assumes that employees are exposed to risks already known. The second one, presented here, seeks to resist a common temptation in organizations: to requalify work situations that are "fragile", saturated with unsolved problems, as a kind of personal frailty, attributed to those who do not tolerate these situations. This leads to the mistake of trying to "fix" workers in order to purge the Real (le réel) of its conflicts. The current management of psychosocial risks cedes too much to this hygienist temptation. The social problem is then translated into the language of health risk. Those who insist on preserving their idea of a welldone job are downgraded to the status of "weak subjects" (CLOT, 2010).

In work psychology, Activity Clinic has been a methodology of work changing for almost 20 years, after developing itself from francophone ergonomics and work psychopathology. It is not a risk analysis, whether physical or psychological. The responsible for the intervention is immediately turned to action, to develop the worker's power to act on their workplace, organization and on themselves. It is not about doing a list of psychosocial risks but about finding with workers the psychological and social resources to perform quality work (CLOT and GOLLAC, 2014), understood as questionable by definition (products, services, collectives, performance).

\footnotetext{
1 This article was originally written in French, what causes a certain number of translation problems. We tried to deal with this difficulty by adding some French words and expressions under parenthesis or between quotation marks whenever translation was especially difficult. Readers interested in the Activity Clinic approach may also see Clot (2009) and Kostulski \& Kloetzer (2014).
}

This is less about a worker who is "exposed" to risk, with its presupposed passivity that requires attention, and more about researching for unsuspected capacity for action in the activity of the latter; it's less about making an effort to promote a "well-being" that is conceived without the worker's participation, often steeped in "good intentions" and expert knowledge, and more about rediscovering with him the pleasures of doing a "good job". For there we find the resource for energy and health. It is less the "QWL" (Quality of Working Life) and more the quality of work in itself that defines the goal of the intervention (TOMÁS and BONNEFOND, 2014).

The intervention described here presents tangible results on the possibilities of transformation of work organization within the perspective of a joint development of health and efficiency through the development of personal, collective and organizational resources (CLOT and SIMONET, 2015). The question of a sustainable transformation of organizations for health and performance is at the heart of the issues that an intervention has to face. It is the case in Ergonomics, in particular, where some defend a model centered on the possibilities of actors to transform their environment (COUTAREL et al., 2015). From another perspective, in management, work on occupational health issues advocates reorienting management to be as close as possible to the real work, through a number of discussion meetings with new decision latitudes for local supervision (DETCHESSAHAR, 2013; BERTRAND and STIMEC, 2011). This framework could thus be better able to mediate the contradictions encountered in action by frontline workers. In general, when public health and organizational performance are at stake, social demand is important to move forward on those issues where work 
is expected to become the central object of management (CONJARD, 2014).

\section{QUALITY OF WORK}

We borrow from Canguilhem (2002) his definition of health, which is not reducible to the absence of disease or even a displayed satisfaction: "I am well, he says, to the extent that I feel able to take responsibility for my actions, to bring things into existence and create between things relationships which would not come to them without me" (2002, p. 68). Therefore, health and power to act are connected for those who work. The passivity that is often imposed on subjects, constrained by a work "neither done nor to do", poisons professional existence. An Activity Clinic must face the challenge of dealing closely with frustrated activity (l'activité contrariée). It must support the revival of a caring attitude towards work, in organizations that request it, legitimated by goals that exceed these organizations: employee's health, of course, but one can also say public health, given the extent of the social consequences entangled by occupational health problems.

To defend work we must tackle it. An expanded professionalism among employees requires the institution of "professional dispute" about the criteria for a work of quality. The "debate of schools" is the condition for the existence of a work collective because it allows to "civilize the real", a real that multiplies the unexpected, and easily divides those who work. Responsibility for the professional act can emerge, which leads to the possibility of gaining authority in work, a state conducive to mental health. However, this "professional dispute" cannot remain restrained to operators. The intrinsic conflict present in the employment relationship, so poisoned in France nowadays, has become too poor, frozen and fixed in role-plays. It can be enriched by experimenting with informed and negotiated conflict between workers and management about the quality of work (CLOT, 2010). A real, sustainable performance can then be realized, contrary to the poor and artificial one that is often built to meet only directors' expectations and criteria. The performance in question here is "dialogic" in the first place. Dialogue becomes the preferred tool of practical performance, to accomplish the workers' power to act on their actual professional environment and on themselves.

Knowingly, the social controversy over the well-done job has no official institution in business companies. But the experience of Activity Clinic in organizations that demand intervention shows that we can establish this conflict by fighting the old habit of "cheating with reality" in organizations. Denial of conflict about the well-done job is currently the normal state of affairs, and it intoxicates social relationships, robs them energy and degrades health. The repression of this flagrant dissonance is currently the main psychosocial risk. Energies are dissipated and resources wasted. Intelligence as well as subjective and collective commitment can only be sharpened within a deliberative dialogical activity: it is discussing things over, examining all solutions that one ends up finding solutions that had not been thought of before, even if they are temporary ones. To transform organizations, "dialogical oxygen" in required; this oxygen can only be produced within the controversies between professionals - and also between them and direction - controversies based on the problems posed by the Real.

Denying conflict about the quality of professional acts is not healthy. Professional dynamism is rooted in the objections and conflicts imposed by the real. The goal is not to attain a sacrosanct "good practice" that should be adopted by everyone. One of the major achievements of the type of clinic that we do, when we manage to conduct it properly, is that criteria for concrete work quality are definitely questionable in nature. In this perspective, what is not yet shared is more interesting than what we already share. If there is a good practice, it is probably that of professional dispute between "experts" and between them and the hierarchy. This is the meaning of Activity Clinic, seen as a development of the collective function: a psychological resource that may be used by every professional (in exchange with the group) in order to develop his own stock of available resources for action; a social function that leads the collective to raise questions about the issues that matter in the organization, constituting itself as a privileged actor of transformation.

\section{METHOdOLOGICAL FRAMEWORK OF ACTION IN ACTIVITy Clinic}

Interventions that follow the Activity Clinic approach are based on a historical-cultural perspective in psychology. The latter is rooted in the work of L. Vygotsky (1997, 1999). For him, "at each moment, a human being is full of unrealized possibilities"2 (VYGOTSKY, 2003, p.76). Observable behavior is a "system of reactions that succeeded" (Ibid., p. 74). Realized and observable activity is therefore only a part of what could have been done. This is what Clot (2008a) conceptualized by distinguishing "realized activity" (l'acivité realisée) on the one hand, and "the real of activity" (le réel de l'activité) on the other. In this sense, the activity carried out has "no monopoly over the real of activity [...] blocked activity (l'activité empêchée) as well as idealized activity cannot be ruled out of the real

\footnotetext{
2 All translations from French references are our own.
} 
of activity" (CLOT, 2008a, p. 66-67). Understood in this way, realized activity is only one component of activity, not all of it. What did not happened, but could have, is also part of the activity. "What could have been done"- the real of activity-is not directly accessible, whether for the subject himself or to an outside observer. That is why it becomes necessary to organize devious means of access, to make it available and to support professionals in the development of their power to act.

For Vygotsky, possibilities that were excluded during the implementation of the action are not directly accessible. That is why he strongly emphasized the importance of "indirect methods" (VYGOTSKY, 2003, 1999) that allow to "double the experience" so that individuals can transform lived experience (l'expérience vécue) of an object into a new experience to live. On this particular subject, Vygotsky has strongly criticized the "dogma of immediate experience" (CLOT, 2011) presented by objective and subjective psychology. Both offered direct access to lived experience, either experimentally or introspectively. From this perspective, Vygotsky's theory constitutes an original methodological proposal to study the development of activity, a third way between objective and subjective methods, in order to have indirect access to "what could have been done", in other words, to have access to the real of activity.

The method for accessing lived experience can only be indirect: it must allow the subject to transform its realized activity into a resource to generate new achievements. In doing so, it is the real of activity that can be changed or reorganized. But one can also take a second important lesson from the work of the Russian psychologist: to study the transformation of action, it is necessary first to induce this transformation. For Vygotsky, indeed, "it is only in movement that a body shows what it is" (1978, p. 65).

Therefore, the intervention methodology attempts to take into account these elements, allowing professionals to say something about what they have done, so that they may also be able to say something about what they could have done. By making performed action visible as one of the possibilities of action - among others - we seek to induce among professionals the development of new actions. This methodology differs from that of ergonomics, which makes activity the direct object of the analysis. Clot (2008b) emphasized this difference:

In work related research, the lesson of Francophone ergonomic tradition (BEGUIN and WEIL-FASSINA, 1997) is to have insisted on the fact that understanding is destined to transform. But we discovered something else: to understand what we seek to understand, that is to say, the mechanisms that develop the power to act, one must transform situations through 'development experiences' (p. 182).
This is why methodological devices are designed, in Activity Clinic, to organize the doubling of the participant's lived experience. Indeed, for Vygotsky, "to be aware of one's own experiences is to have them available as objects to other experiences" (1994, p.42). For him, "such a doubled experience allows man to develop forms of active adaptation" (VYGOTSKY, 2003, p. 72) and it is this process, in Activity Clinic, that allows the development of the power to act.

Developing the power to act supposes an intervention that tries to ensure that the participants' experiences become for them a means to live other experiences. Methodological devices in Activity Clinic seek to organize this "doubling" of experience to develop plasticity between the experiences lived by the subject. Crossed self-confrontation is designed to allow this kind of development of the experience. In this dialogical context, professionals can possibly make their lived experience a tool to live other experiences (CLOT, 2003).

\section{THE METHOD OF CROSSED SELF-CONFRONTATION: DEVELOPING THE PSYCHOLOGICAL FUNCTION TO DEVELOP THE SOCIAL FUNCTION OF THE "WORK COLLECTIVE"}

The method of crossed self-confrontation can be summarily described in three general phases. The first phase is dedicated to the creation of a group of volunteer workers to perform the analysis of their activity and to determine which shared activity sequences will be video recorded. The second phase involves three steps: 1) conducting the video recording; 2) the confrontation of the professional with the video recording of his own activity in the presence of the researcher (simple selfconfrontation); 3) confronting the same professional to the same video recording in the presence of the researcher and a fellow worker who will also be facing his own activity (crossed self-confrontation). The third and final phase of the method is to organize the issues collected during the previous phases and discuss them at different levels of the organization (CLOT et al., 2001; DUBOSCQ and CLOT, 2010). The research of controversy is at the heart of the crossed self-confrontation method. The method aims to develop what Clot (1999) has called "the psychological function of the work collective", as well as its social function. Restoring the psychological function of work is to develop in the collective a "sense of living the same story," in the present case through the crossed self-confrontation method of co-analysis. For this, the responsible for the intervention tries to support the elaboration of professional experience in the course of the sessions of self-confrontation, in order to build a 
collective and deliberated professionalism (CLOT and GOLLAC, 2014), in which the criteria for quality workthe "well done job" - can be discussed.

The collective considered here draws its power to act from its capacity to elaborate disagreements. Disagreements are important because they bring out conflicts that professionals have in common, but that they have answered differently. Professional "dispute" represents a privileged clinical instrument in the context of this method.

When it is "alive" in the workplace, the collective can be a resource for individual activity. When the exchange about practical activity is allowed, even encouraged, or simply possible, the collective can produce implicit rules, which are all resources to work effectively. This psychological function of the collective protects the subject, not leaving him alone when facing organizational contradictions and battles. The psychological function of the collective establishes a "responding professional" who gives advice to situated individual activity. Without it, the subject's health is threatened, because he is isolated "facing all the extent of possible nonsense" (DARRE, 1994). "The failure [...] of the collective protection over individual activity degenerates personal activity, exposing it to various forms of work psychopathology" (CLOT, 2002 , p. 31). One of the main goals of an intervention in Activity Clinic is to restore this collective function. Crossed self-confrontation method is an important means of action to achieve this purpose. The intervention aims to revitalize the psychological function of the work collective through activity analysis.

In this perspective, the collective is established by its ability to support the "debate of schools", because these debates are the ones that allow the collective to "civilize the real" (civiliser le réel) (CLOT and GOLLAC, 2014, p. 133). "An expanded professionalism among employees supposes the institution and elaboration of "professional debates' on the criteria of quality work" (ibid.). Here, "professional dispute" is the criterion that defines the work collective - a collective based on a Vygotskian approach to conflict.

When work collective is revitalized by instructed conflict, it can acquire a social function as a resource for the organization of work. For this, the clinical activity of circulating conducted analyzes at different levels of the organization (with other colleagues, management, steering committees, etc.) is necessary to enable the development of the collective social function in the organization, so that it can become an instrument of the organization, not just its object. Here, an explanation is needed: the development of the social function of the collective, one of the goals of the self-confrontation method, changes status, and becomes an instrument to produce changes in the organization. In the example we will give latter, the social function of the collective, renewed through dialogue, became an instrument, not to produce more dialogue, but above all to "produce organization", that is, to institute a "conflictive cooperation" among professionals, unions and management, producing concrete transformations. Then, the development of the social function of the collective is not only aimed to "restore" damaged dialogue in the organization or in the collective; it seeks primarily to lead dialogue to the transformation of concrete work situations that are considered problematic.

\section{AN EXPERIMENTAL DEVICE OF DIALOGUE ABOUT THE QUALITY OF WORK IN THE FACTORY OF REUNAULT FLINS}

\subsection{A device with three levels}

To develop the approach previously explained, we will talk about the experiment conducted with Renault in the Flins factory. The experiment started after a request from the direction of the company, and the request came when social dialogue at the highest level of the company reached a dead end. The request concerned the assessment of working conditions in terms of quality and health. Our proposal, accepted by all, was not to arbitrate these disputes, but to experiment on many levels of the company using dialogue devices about the quality of work (understanding quality as conflictive by nature), in order to build new organizational compromises that are source of health and performance. It was agreed to take the experiment to the factory and to the engineering department, but our discussion here is limited to the Flins factory.

The basic device of the experiment articulates three main levels. The first one is that of the workshop, an Elementary Work Unit (EWU) for door assembly. The second one is the factory level, with a local committee that gathers local and central unions, the directors of the factory, factory management and hierarchy, the Human Resources Department (HRD), company health service, and, at the right time, also the chain operators. Finally, the third level, that of the company, a national steering committee that replicates the same structure with the directors of the company.

Action begins with a long period of observation, as close as possible to the work of the operators in the assembly line, to build, with those who request it, a joint analysis of their work. For that purpose we use the crossed self-confrontation method (CLOT et al., 2001; CLOT, 2008a). After filming performed activity, it is time to engage in professional dispute between experts, without the participation of hierarchy. This is the time for collective work around the controversy over the well-done 
job (with its pleasures and displeasures), which aims to develop the collective psychological function to imagine new possibilities of thinking and acting. Then, the results produced are presented under the form of an edited video, and they are discussed in the steering committees. Thus, the collective changes place in the course of the intervention: it is primarily a means of developing collective resources to individual action, and secondly it becomes a means to change the organization of work through the steering committees in which the quality criteria may be discussed again between professionals and their hierarchy.

In the door's EWU, after we presented ourselves and spent some time watching their work, twenty of them volunteered to engage in crossed self-confrontations, among them "temporary workers" and "Renault workers", divided between two teams and involving ten different occupations. The EWU has about 35 occupations; two teams cover 16 hours of manufacture. Each team has 35 chain operators, 3 senior operators (SO) who are not located in the chain, but are involved in problem solving and adjustments, and a head of the team, an Unit Commander (UC). Temporary workers account for $80 \%$ of the workforce in a team and $50 \%$ in the other; turnover is high. Two rows of posts are distributed face to face along the EWU, those of left doors and those of right doors. The doors are suspended on a swing in pairs (left and right doors), then a rail leads them to the EWU. After that, they are successively "cabled", "glassed", "dressed" and "equipped" to be then transported to another EWU where they are assembled to the vehicle being prepared on the main chain.

\subsection{The first self-confrontation cycle and its results: repressed dialogue and spoiled performance}

There is no assigned time to dialogue in the organization of work. Almost all of the operators' time is directly productive, with the exception of two breaks. There are also planned stops called "Animations", seven minutes a week and twenty minutes a month. In fact, these breaks are not systematic and are easily used by management to soften workflow hazards (for example during an outage). The unit commanders receive a message on a computer system, sometimes a few minutes before the animation, showing the topics they must communicate to operators. This is a form of top-down communication that provides information or reminders of various requirements on quality, safety and behavior. It may give the opportunity to some questions and answers, but time and subjects are usually unknown in advance to operators, being brought by the initiative of management. It is in this context, after a lot of observation and dialogue with the station operators, that twenty of them have engaged in crossed self-confrontations, resulting in a video validated by them and sent to the steering committee.

The work activity is at first an object of discussion between operators, before becoming an object of dialogue within the steering committees. The films diagnose the quality of real work from the perspective of operators, and have the role of putting everyone in tune with these assessments, opening the discussion. This particular video presented the commitment of operators with their work, the quality and ingenuity of their analyses, but also compensations made, sometimes at the cost of their health, as well as problems related to the design of certain parts or related to the post organization. It also revealed what we described as "useless speech", that is to say, the repeated experience of speaking, proposing, and not seeing the message go beyond the hierarchy's first level, making it impossible to change work settings. This experience of worthless speech resulted in a shared feeling that it was pointless to speak, because words had lost their influence on people and things.

This first phase went from the collective work between operators in the workshop to the dialogue at the level of steering committees, with the participation of direction, management and labor organizations. It laid the foundation for the institution of dialogue about the conflictive quality of work. Nobody could escape dealing with work as it was, as it should or as it could be, but everyone was able, because of the experimental device, to engage in dialogue to change it.

\subsection{From the dialogue between operators to operators-management dialogue: dialogical conflict and power to act in the workshop}

While all positions have been redesigned to launch two new vehicles, we organized discussions about three posts of the workshop that were considered by operators as especially problematic in relation to superiors (Unit Commander and Workshop Commander). The operators of these positions have engaged in a second cycle of co-analysis through crossed self-confrontation. The videos produced at the end of this second phase of joint analysis were used in the dialogue between operators and supervisors in order to act on the raised issues. These meetings were conducted by clinicians in a dialogical framework, and produced crucial results for the organizational changes that will follow.

The framework of the experiment served to build the technical and social conditions for dialogue, so that conflictive views on the quality of work and hierarchical relationships were in a productive tension. This is a very important point in the kind of intervention described here: clinicians must guarantee the primacy of "the real" 
over social relations, in order to prevent the repression of the real and a comeback to "business as usual". This means, for example, that the clinician must intervene in dialogues to prevent views or arguments to be dismissed solely because of subordination. For this to happen, clinicians must maintain a dialogue about these issues with supervisors, in order to elaborate these questions with them in another level of the device.

Thus, operators have engaged in a device for dialogue that allowed them to diagnose obstacles to the effectiveness of their own work. They made the experience that these obstacles could actually be discussed with management. Among these obstacles, some have changed, while others were not repressed anymore, becoming objects of dialogue to be elaborated beyond this perimeter. To management this was more or less difficult, depending on the themes addressed (we will say more about their work activity below), but it was also a resource for at least two reasons. The first one is that the quality of the analysis and of the dialogue practiced in the device has helped solve performance problems that were initially ignored. The second one is that it became possible for them to assert their decisions, explain their constraints, impossibilities and limitations, which were previously silenced and sometimes ignored by operators. The planning of positions was one of the discussed questions, but also problems related to tools and to the arrangement of assembly operations. Effective changes were also made beyond the EWU, going all the way to the modification of the design of a piece by engineering. Untreated problems that have been brought up in the EWU dialogues have become the subject of dialogue with social partners in the steering committees (for example, the articulation between manufacturing and engineering and the number of temporary workers).

\section{- An example of dialogue between the work collective and it's hierarchy on the parts known as glass run channels ("coulisses")}

Glass run channels ("coulisses") are silicone rubber joints in which the glass slides, and must be assembled one in each door. They also act as a seal between the door and the metal sheet. Considered by all as particularly problematic, the assembly of glass run channels will be the subject of a new dialogue session with management, after going through crossed self-confrontations in each team. The glass run channel of the front door has design issues that causes problems when combined with the metal sheet. This produces a number of difficulties in the operators' assembly activity. In reaction, they lubricate the part to facilitate insertion.

Dialogue with management started pointing out the time required for operators to carry out the lubrication of the part. However, this was not enough to settle all the difficulties of the task, which also included other operations.

The dialogue session between operators and management about this workstation was held with glass run channels operators, ten other operators willing to participate (including two Senior Operators), two Unit Commanders (UC) and the Workshop Commander (WC). This particularly rich session has contributed to several changes. The 20-minute video, which supported the session, was produced by crossed self-confrontations made by each team on the glass run channels workstation. They had raised and analyzed the following issues:

- Different gestures and techniques mobilized to facilitate the installation of the glass run channel lead to a controversy about the pace: should we favor a rapid one followed by a pause, or a slow and steady one, without stopping?

- The lubricant (propylene glycol) is debatable; some do not use it because it gives them skin problems. They use soapy water taken from the bathroom;

- Lubrication has another consequence: after use, the soil is wet and slippery, what may cause falls. To fix that, operators have obtained retention containers to be placed under the glass run channels holders, while requesting a newly designed glass run channel as a solution;

- Some solutions found by operators to optimize their movements are in disaccord with the prescribed mode of operation, for example, the use of a nearby trash can as an intermediate support of glass run channels;

- A failure of the process generates the regular fall of a box of parts, causing waste of time and deterioration of the material. The operators try to find movements to prevent the fall. They express resentment and misunderstanding when they analyze possible reasons to the lack of interest of the organization in solving a problem that costs in more than one sense: "It hurts when you see a mirror fall to the ground, if it breaks that's 150 euros, that's money", "it's fine to think about production, but we must also solve work problems";

- Change of positions between operators is not done, when it would lead to the development of professionalism and health.

Let us examine in detail one of these issues, that of lubrication, following its development in dialogue until the transformation of the work procedure. Putting self-adhesive foam is one of the operations that must be performed in the glass run channels workstation. However, taking this foam with wet gloves alters its adhesive character, so that it does not hold and ends up 
falling, generating problems that must be taken care of. Besides, another metal piece called "nut cage" is difficult to handle with wet gloves, and often tears them in such a way that the lubricant reaches the hands of the operator, generating skin problems.

During the discussion, a proposal is made to modify the procedure by placing other pieces ("molaires"). But the path that led to this proposal was not an easy one. It required the operators to explain the problem, even if they did not had any solution to propose. The workshop commander agreed with the diagnosis and recognized the abnormal character of the difficulties presented. $\mathrm{He}$ explained the causes, the price of the lubrication solution, and what management and direction had already done, but he did not know how to do more. Faced with this impasse, in difficulty, he refers the issue to operators: "what do you propose?". This causes a reaction of refusal by one operator: "what do we propose! It is you who must propose!". While the situation could deteriorate, exchanges with other four operators lead to the concrete and relevant proposal of using "molaires", mentioned in the beginning of this paragraph.

However, this proposal involves questioning the number of operations to be performed in the cycled time of the workstation, which in turn changes the number of operations of another workstation, creating a new dialogical confrontation. The UC seeks to enforce a status quo that will result in a direct opposition by one operator (union leader): "If we must change the number of operations, we will change them, huh, that's all! The idea is to find a solution, that's all." In the end, the workstation will be changed indeed. In the following dialogue transcription, we can read the details of that interaction.

\section{ABBreviations: UC = Unity Commander $/$ WC $=$ Workshop Commander $/$ SO $=$ Senior Operator $/$ OP1, OP2, OP... $=$ Operators $/$} Psy = Psychologist

OP1: Your gloves, you're forced to let them humid in order to pull the lip (of the glass run channel). Then you take the foam like that, and when it is wet, it does not hold up. Most times, there are foams that fall on the chain and people down there, they go back to pick and assemble them. Each time it falls, you cannot well put them if your gloves are not dry.

Psy: That's true with soap, but is it with the product?

OP1: The product is no good either for people who work in the chain. I had problems at first when I got here, there were green gloves but they were too small. When I wore them they lasted about half an hour, after that they were torn, the product got in. When I went home I was taking a shower when I saw my hands were swollen, I had a finger I had a problem you see, it was because of the product. Right now there are gloves with the right size, but the problem is still there, we must find a solution.

OP2 (union leader): The solution is to change the glass run channel so that all these problems go away. To change it in such a way that there will be no more need for a liquid or anything. There will be no such risks, no more problems with things that do not stick. It is the glass run channel that we must change, that we must revise in such a way that it can be set without having to stick and that it goes well.

WC: We completely agree, in fact, the product we put on the glass run channel is a temporary solution, I consider it temporary, it is not a definitive answer, we've been taking measures; you (to PSY) have been in several meetings with us, where we spoke to higher hierarchy, you even had visitors, the person who was there this week, he is the director of quality in Renault. So he's not just anyone, I showed him that in fact the glass run channel was impossible to assemble like that, and that we had soapy water, propylene glycol and that it was a temporary solution that had been there for several months now and that we could not continue like that. We are unable to put the glass run channel properly in the front, which is seen in the finished cars, we see that, when closing the door, the glass run channel does not shut.

Several voices at once: Yes, it stays half opened.

WC: It appears in the customer's quality and in the finished car. It's true that this is not a V1, but it's almost a V2 ${ }^{3}$. A customer does not see it, all customers will not see, but some good customers will see it. We have, the whole company has only one interest: to improve quality, but quality goes with working conditions. That is why this person came; Flins management requested his presence to explain that we cannot do vehicle quality if we don't have pieces that assemble correctly. So I completely agree, but my problem now is that I don't have a deadline for the implementation of the final solution. This is why I'm in trouble with you, of course. Second thing: why propylene glycol and not soapy water. We made measurements with soapy water and assembly efforts are $13-14 \mathrm{~kg}$. Besides, if we do not put enough or if it dries, you mount to efforts of 21-22 kg, we've measured it. It's measured with a dynamometer. Propylene glycol is down to $9 \mathrm{~kg}$ of effort. Which is not...

OP3 (glass run channel operator who has no problem with the skin lubricant): Especially over time, we have $7 \mathrm{~h} 30 \mathrm{~m}$ of work.

WC: We agree.

\footnotetext{
${ }^{3}$ System that qualifies the intensity of problems from V1+ to V3
} 
OP3: There is a big difference between soapy water and the product.

WC: That's why we put propylene glycol, and I can tell you each 5 liter can, how many of them we order, SO?

SO: 4 cans each week.

WC: 4 cans a week, how much does it cost?

SO: 80 euros.

WC: 80 euros a can, 4 cans a week, you can see how much we lose per week. This is what I showed the quality director too. I said to him that this problem was happening, and I showed also the lickers, $25 \%$ of the lickers are broken, this is astonishing, roughly $€ 1,500$ / week. So in fact there is also an economic gain. I tell you, everything is connected; working conditions are not only working conditions. They are linked to quality and cost.

OP2: Yes, the problem about propylene glycol is that there are guys who have their hands damaged because of it. There's a guy who came to tell me that when he gets home, he removes his skin.

Many: Yes, that's true.

WC: What shall we do? We ordered green gloves that go below the normal gloves, so you have a double glove, green gloves to protect skin, black gloves to protect the operator and besides we ordered a cream that was given to you.

Many: We have never received it.

WC: I brought it myself.

Hubbub

WC: If there is a cream problem we will order it.

Hubbub

OP4: The problem is that we cannot work with green gloves, it bothers us. We do not feel the pieces, we have small pieces to attach, and if you do not feel them, they may fall, you lose time, we lose a lot of time.

(everyone speaks at the same time)

Psy: one at a time, one at a time.

OP4: The nut cage!

OP2: The nut cage will tear their gloves.

OP4: And the lubricant will go inside.

OP2: And the product, it has a problem with the foam. When you touch, when you have the misfortune of touching the foam with the product, it does not stick anymore.

OP4: It slips, you hold the nut cage and it falls.

WC: Ok, that's fine, what do you propose?

OP4: What do we propose! It is you who must propose!

OP5: Do not put the foam, put something else.

OP4: Yes, something that doesn't make us lose our time, because a lot of time is being lost.

OP2: Those who use the product should not use the nut cages.

OP5: We could replace it by "molaires".

WC: This is something we can look at, good idea! That's a good proposal.

OP5: Replace the nut cage with "molaires"

UC: This changes the number of operations... we can look at it. But I'm not sure if it's possible, that's what we have to...

OPS: It's the same for the small pieces, they must be elsewhere.

UC: But this disturbs everything.

OP6: There are dexterity problems because of that.

Hubbub

OP2: If we must change the number of operations, we will change them, huh that's all! The idea is to find a solution, that's all!

Hubbub 
The problem with the glass run channel design will persist despite its recognition by engineering, and the number of operations will be changed. The foam and the "nut cage" will be replaced by "molaires", retentions containers will be put under the glass run channels' holders to prevent the liquid from falling to the floor, and the post will be redesigned based on the optimization of the operator's movements. Falling boxes will also become a discussed topic and possibilities will be tested until the solution of the problem. A third workstation will also be a part of the discussion and will pass through changes conceived by operators themselves.

The effectiveness of this dialogical process will be recognized by everyone involved, operators and management, both in terms of the problems that were solved as in terms of the improvement of work relationships, despite tensions and confrontations related to the conflictive nature of the criteria to evaluate the performance. This is particularly the case between the managerial criteria for measuring theoretical economic performance, and those of sustainable and real performance at workstation, causing management to repress dialogue because solutions will degrade productivity indicators. This is also the case when dealing with the problem is out of the scope of the manager: for example, changing the design of a part or changing the high rate of temporary workers that prevents the change of positions in the workstation. Therefore, work organization and current social relationships may become forces that repress dialogue, leading to "non-performance" or artificial performance.

In the end, it was understood that problems had no reason to stay untouched. They can be discussed and solutions can be found: dialogue is a means of enriching work organization and bringing untreated problems to the light. In addition, if dialogue is an instrument, it is also an outcome, because it helps to develop a shared experience where you can talk about work problems without escaping them, as hard to solve as problems may be. One must emphasize that these benefits are not possible if dialogue is not followed by concrete actions.

It also affects professional relationships, or, as they say in the factory, the "social climate" gets better, understanding becomes easier, and efficiency grows. Finally, and this is a decisive point for what happens next, operators engaged in the experimental device at the doors workstation have become, over time, more and more able to discuss work with colleagues, with their superiors and in the steering committee. In a sense, the exercise of dialogue about their activity with their colleagues and with the hierarchy has made them interlocutors of reference in the EWU.

These results were the subject of a steering committee, where for the first time operators have taken place as direct interlocutors in the dialogue. Discussions involving operators and management, but also social partners and direction, have considered achieved results conclusive, and focused on the importance of imagining a way to generalize the "experiment made at the doors". Consequently, several questions arose. Besides the material conditions of time, space and equipment to sustain dialogue, how could it be done without the help of the experimental device embodied by the members of the CRTD-CNAM ${ }^{4}$ ? How to ensure operators' initiative? How to prevent issues from being forgotten, devaluating dialogue and speech?

The proposal is made to create the function of the "referent operator" that would be elected by his peers to be the interlocutor for quality of work within a process yet to be invented. Discussions led management to retain this principle of the "referent operator" elected by his peers and to decide to build an organizational system for deploying it all over the assembly department. The process of dialogue and action on the quality of work was going beyond the experimental scope of the EWU responsible for the doors.

\section{DEVELOPING ORGANIZATIONAL RESOURCES: ELECTED REFERENT OPERATORS}

The director of the factory has chosen the workshop commander, together with CNAM members, four "doors referents" and two UCs to design and test the process in question. In the end, the basic structure is the following: the referent operator, elected by his colleagues, goes from workstation to workstation to see all operators and to collect what they have to say about their work, their difficulties and possible solutions. This monthly gathering must be complete, accurate and written by the referent. Afterwards, he meets his counterpart on the other team; they compare and aggregate their data. Based on discussions with colleagues, they try to establish which are the most important subjects (critical problems, security problems, old problems, etc.) and they prepare the next step, the appointment with two unit commanders.

During the appointment with management, referents will present all topics that were collected and discussed with operators, and pick those they wish to give priority to. They discuss and analyze options to solve them. Problems are then categorized and oriented, according to their complexity, to the proper scope of responsibility (unit commander, workshop commander, department commander).

\footnotetext{
4 Laboratory responsible for the intervention. CRTD $=$ Centre de recherche sur le travail et le développement; CNAM = Conservatoire National des Arts et Métiers.
} 
Possible solutions are included on the agenda for implementation, and some issues who require further analysis are sent to another place for elaboration. Everything is recorded in a "Unified List of Issues" (ULI): a computer file where each line corresponds to a problem, followed by the necessary information (category, analysis, solution, deadline, pilot, etc.). This file is then printed and displayed in the EWU.

Every week the referent will have some time away from the chain to follow how issues are being treated, and to see the operators concerned, to check if they validate the implemented solutions. This is a condition to consider a problem closed when meeting with management during the next appointment.

Every 15 days, the chain stops for 20 minutes: it's "DQW" (Dialogue for Quality of Work). This is the time when all operators, the referent and the UC discuss all collected issues, processed, in treatment and not treated. This is done using the printed form of the ULI displayed in the EWU space.

This prototype designed and tested "at the doors" but also discussed with unions and management has been validated by local steering committee, and then validated by the national committee for deployment throughout the assembly department.

\section{THE INSTITUTION OF QUALITY WORK: DISCUSSING TO DECIDE}

It is important to emphasize some points. This is not merely a discussion of work issues, "free speech" or a way to allow "expression". The elected referent establishes the function of the work collective as an instrument of action in the organization.

This is a process that articulates many different things: the list of problems and possibilities, hierarchy, discussion, decision, validation and control of the device. Indeed, a referent operator is designated by the referents themselves and is charged one day per week to ensure the operation of the device. He does so by circulating in the workshops and reporting it to the guarantor of the device previously appointed by the direction. It is important to stress the link between dialogue and decision because the simple expression of the employees has showed to be a failure in the past.

The elected referent operator embodies a new professional authority, legitimized by operators. In this sense, it is an institutional force of the work collective to bring down the organization and unions to the level of real work. "To bring down the organization" and not "communicate the problems all the way up" because the tendency, despite all good intentions, is to see problems loose force as they go along the chain of command, soon to be forgotten as other priorities are chosen according to other quality criteria.

Regarding performance and health issues, the organization of decision at the right level is a very important but complex topic, because it touches the issue of authority. To think about it we can use the political concept of subsidiarity (PETIT, DUGUÉ and DANIELLOU, 2011; DETCHESSAHAR, 2013). According to this principle of public policy, we must be careful not to do at a higher level what can be more effectively done at a lower level. Thus, applied to work organization, we do not do at a level $\mathrm{N}+1$ what can be done by $\mathrm{N}$. But the $\mathrm{N}+1$ level must intervene when problems exceed the capacity of the $\mathrm{N}$ level.

In our view, the referent allows the exercise of this principle; he is an instrument to the practice of subsidiarity in the organization. Decision-making is a central question: subjective commitment and initiative are essential to the performance of the organization. To be prevented of effectively contributing to decisions in work is a principle that opposes it. Bernoux (2015) states the psychological and social implications of such impossibility: "Being unable to participate in decisions about one's own work is like being denied recognition of this work. This is unfair." (p. 182).

In the spring of 2014, 600 operators of the assembly department elected their 26 EWU referents who have been trained and accompanied by experienced referents. A year after launch, the device is still operational and its assessment is positive. Referents believe it is impossible to go back because of the great number of problems that had no voice before and that can now be treated. Management and four unions, with their differences, agree on the importance of the thing. Over 1000 issues were collected, of which over $70 \%$ are solved; there are fewer health problems and a drop in absenteeism rates where the operation of the device was optimum.

Moreover, without being able to develop this subject, many questions arise about the effects of such a device in managers and beyond. This can be unsettling and this is especially so for some who have made the repression of real work problems an habit. For others, it is quite the contrary, such a device, far from weakening, is a resource for their own authority to act on the issues of the EWU, on the effectiveness of the team, and therefore strengthen their own legitimacy as leaders. In both cases, we are talking about the relationship between affect and action (CLOT, 2015). This relationship is central to the activity of intervention, which aims to interpose a dialogical and transferential framework (SCHELLER, 2013), where the affective experience that is present in any activity has to become a way of developing the power to act on oneself and on the work environment. A device similar to 
that of the operators is currently being made with Unity Commanders. They have designated their own referents to hear and act on their own obstacles with hierarchy.

In the fall of 2015 , the device is deployed in all departments of the factory. The steering committees have become forums where the effectiveness of the device is discussed and assessed as well as the expansion of the device to the rest of the factory and beyond. This plural assessment based on the criteria of many actors allows the experience of another "social dialogue": that of a conflictive cooperation (TRENTIN, 2012) directly based in real work.

\section{REFERENCES}

BERNOUX, Philippe. Mieux-être au travail: appropriation et reconnaissance. Toulouse: Octarès, 2015.

BERTRAND, Thierry; STIMEC, Arnaud. Santé au travail: voyage en pays de lean management. Revue française de gestion, v. 5, n. 214, p. 127-144, 2011.

CANGUILHEM, Georges. Ecrits sur la médecine. Paris: Seuil, 2002.

CLOT, Yves. La fonction psychologique du travail. Paris: Presses Universitaires de France, 1999.

CLOT, Yves. Clinique de l'activité et répétition. Cliniques méditerranéennes, v. 2, n. 66, p. 31-53, 2002.

CLOT, Yves. La conscience comme liaison. In: VYGOTSKI, Lev. Conscience, inconscient, émotions. Paris: La Dispute, 2003. p. 7-59.

CLOT, Yves. Travail et pouvoir d'agir. Paris: PUF, 2008a.

CLOT, Yves. Le statut de la critique en psychologie du travail: une clinique de l'activité. Psychologie Française, v. 53, n. 2, p.173-193, 2008b. https://doi.org/10.1016/j.psfr.2008.02.002

CLOT, Yves. Clinic of Activity: the dialogue as instrument. In: SANNINO, Annalisa; DANIELS, Harry; GUTIÉRREZ, Kris D. (Org.), Learning and Expanding with Activity Theory. Cambridge: Cambridge University Press, 2009. p. 286-302.

CLOT, Yves. Le travail à cour. Pour en finir avec les risques psychosociaux. Paris: La Découverte, 2010.

CLOT, Yves. Théorie en clinique de l'activité. In: MAGGI, Bruno (Org.). Interpréter l'agir: un défi théorique. Paris: PUF, 2011. p. 17-39.

CLOT, Yves. Les affects et l'action, In: Clot, Yves. La fonction psychologique du travail. 6ème éd. Paris: Puf, 2015. p. VII-XII.

CLOT, Yves et al. Les entretiens en autoconfrontation croisée: une méthode en clinique de l'activité. Éducation permanente, n. 146, p. 17-27, 2001.

CLOT, Yves; GOLLAC, Michel. Le travail peut-il devenir supportable? Paris: Armand Colin, 2014.
CLOT, Yves; SIMONET, Pascal. Pouvoirs d'agir et marges de manœuvre. Le Travail Humain, v. 78, n. 1, p. 37-49, 2015.

CONJARD, Patrick. Le management du travail. Une alternative pour améliorer bien-être et efficacité au travail. Lyon: ANACT, 2014.

COUTAREL, Fabien et al. Marge de manœuvre situationnelle et pouvoir d'agir: des concepts à l'intervention ergonomique. Le Travail Humain, v. 78, n. 1, p. 9-29, 2015.

DARRÉ, Jean-Pierre. Le mouvement des normes, avec Bakhtine et quelques agriculteurs. In: DARRÉ, Jean-Pierre (Org.). Pairs et experts dans l'agriculture. Toulouse: Erès, 1994. p. 15-29.

DETCHESSAHAR, Mathieu. Faire face aux risques psychosociaux : quelques éléments d'un management par la discussion. Négociations, v. 1, n. 19, p. 57-80, 2013.

DUBOSCQ, Julie; CLOT, Yves. L'autoconfrontation croisée comme instrument d'action au travers du dialogue: objets, adresses et gestes renouvelés. Revue d'anthropologie des connaissances, v. 4, n. 2, p. 255-286, 2010.

KOSTULSKI, Katia; KLOETZER, Laure. Controversy as a Developmental Tool in Cross Self-Confrontation Analysis. Outlines. Critical Practice Studies, v. 15, n. 2, p. 54-73, 2014.

PETIT, Johann; DUGUÉ, Bernard; DANIELLOU, François. L'intervention ergonomique sur les risques psychosociaux dans les organisations : Enjeux théoriques et méthodologiques. Le Travail Humain, v. 74, n. 4, p. 391-409, 2011. https://doi. org/10.3917/th. 744.0391

SCHELLER, Livia. Travail, affects, activité transférentielle. @ctivités, v. 10, n. 2, p. 249-260, 2013.

TOMÁS, Jean-Luc; BONNEFOND, Jean-Yves. De "l'épuisement professionnel" à la qualité du travail: le cas de la "belle table d'instrumentation". In: LHUILIER, Dominique (Org.). Qualité du travail, qualité au travail. Toulouse: Octarès, 2014. p. 129-140.

TRENTIN, Bruno. La cité du travail. Paris: Fayard, 2012.

VYGOTSKI, Lev. Mind in society: the development of higher psychological processes. Cambridge: Harvard University Press, 1978.

VYGOTSKI, Lev. Défectologie et déficience mentale. Texts published by Koviljka Barisnikov et Geneviève Petitpierre. Lausanne: Delachaux et Niestlé, 1994.

VYGOTSKI, Lev. Pensée et langage. Translation by Françoise Sève. Paris: La Dispute, 1997.

VYGOTSKY, Lev. La signification historique de la crise en psychologie. Translation by Colette Barras and Jacques Barberis. Lausanne et Paris: Delachaux et Niestlé, 1999.

VYGOTSKI, Lev. Conscience, inconscient, émotions. Translation by Françoise Sève e Gabriel Fernandez. Paris: La Dispute, 2003.

Submetido em 18/06/2016 Aprovado em 25/11/2016 